\title{
Estado de prontidão: pesquisa performativa e colaboração nos processos de criação interartística em Converse
}

\author{
Lia Günther Sfoggia \\ Guilherme Bertissolo \\ Luciane Cardassi \\ Universidade Federal da Bahia
}

\section{Resumo}

Este artigo enfoca os processos de criação interartística colaborativa na obra Converse, para uma performer, piano e eletrônica/vídeo em tempo real, com duas projeções de vídeo. Considerando a escassez de trabalhos que abordam os processos artísticos de criação colaborativos para além dos relatos pessoais e/ou autoetnográficos, buscamos aqui desvelar um caminho metodológico que considera a imbricação entre teorias e práticas - conforme formulação de Lima -, numa abordagem colaborativa para a pesquisa performativa - conforme Haseman, Fernandes, Bacon e Midgelow -, mediada por um conceito oriundo de um contexto cultural: a Capoeira Regional.

Palavras-chave: Pesquisa performativa. Colaboração. Processos criativos. Estado de prontidão. Capoeira regional.

\section{Introdução}

Este artigo enfoca a criação interartística colaborativa, tomando a pesquisa performativa como horizonte metodológico. O processo criativo tomou como ponto de partida o conceito de Estado de Prontidão, inferido no contexto da Capoeira Regional na Fundação Mestre Bimba. O próprio contexto, como ambiente de jogo, apresenta diversos modos colaborativos que possibilitaram a exploração por parte dos colaboradores. Pretendemos, então, desenvolver uma abordagem colaborativa para a pesquisa performativa, mediada por um conceito oriundo de um contexto cultural.

Esse é um esforço que busca, além da dimensão do fazer artístico performativo em colaboração, provocar e questionar questões de hierarquização e subalternidade entre arte e cultura, evidenciando a capoeira como um contexto dinâmico e capaz de transcender o papel de mera inspiração (SFOGGIA, 2019). Esse é um posicionamento que traz os estudos culturais - no caso, através da capoeira -, para o topo de uma pesquisa acadêmica que se 
aprofunda no processo de experienciar a manifestação, não para discorrer sobre a história ou apropriar-se de materiais - seja de som ou movimento - num sentido representativo, mas para evidenciar sua capacidade de escancarar estratégias de manutenção no tempo, já que, considerando que essas se mantêm continuamente pertinentes com o passar dos anos - isso seja então possível. Falar sobre cultura é muito relevante, principalmente se consideramos que é uma estratégia fundamental da permanência e perpetuação das manifestações da cultura popular: a transmissão oral. No entanto, entendemos que esse é um aspecto que já vem sendo explorado e fomentado por pesquisadores da cultura. O que propomos aqui é trazer a Capoeira Regional como propulsora de um contexto de criação interartístico, baseado em sua cosmologia.

Como já referimos em textos anteriores (CARDASSI; BERTISSOLO, 2020, p. 8), trabalhos recentes sobre colaboração têm enfocado relatos pessoais e/ou autoetnográficos. Acreditamos que, dado o caráter único de cada processo artístico, em especial no contexto da colaboração interartística, esse tipo de depoimento é benfazejo. Entretanto, é necessário que busquemos caminhos metodológicos, na busca por uma imbricação entre teorias e práticas nos processos criativos, de modo a formular questões e conceitos que apoiem e permitam um horizonte em comum de pesquisa. Essa perspectiva está contemplada no trajeto de pesquisa performativa, aqui abordado, e no contexto da composicionalidade formulada por Paulo Costa Lima (2012).

Este artigo tem contexto na pesquisa de doutoramento de Sfoggia (2019), realizado no Programa Multidisciplinar de Pós-Graduação em Cultura e Sociedade da UFBA, na linha de Cultura e Arte. Essa pesquisa enfocou processos criativos em dança a partir de uma vivência de campo no âmbito da complexa rede de saberes da Capoeira Regional, especialmente no que tange a dimensão de movimento, levando à identificação de conceitos que emergiram tanto da multidimensionalidade da própria experiência - aí incluídas observação e análise - como do entrelaçamento desta com um mergulho em campos distintos da literatura, capaz de estabelecer um diálogo com as questões ali construídas, visando assim a invenção de caminhos e possibilidades (teóricas e práticas) para criação e performance de novas vivências artísticas.

Buscamos discutir aqui um percurso metodológico que culminou na criação de uma obra interartística. O processo de criação em questão foi desenvolvido por três artistas de diferentes backgrounds. Uma performer, que atua também nas artes da fotografia e vídeo(dança); um compositor que atua também no desenvolvimento de estratégias de processamento de eletrônica e vídeo em tempo real; e uma pianista, cuja atuação como pianista também possui larga experiência em processos colaborativos e multimídia. A obra desenvolvida foi Converse, para uma performer, piano e eletrônica/vídeo em tempo real, com duas projeções de vídeo. 
O artigo está dividido em três partes, além desta introdução e das considerações finais. Primeiramente, discutimos a perspectiva da pesquisa performativa e a colaboração nos processos criativos. Em seguida, discorremos sobre o conceito de Estado de Prontidão, que permitiu a elaboração da obra Converse. Finalmente, abordamos os processos criativos à luz da noção de colaboração na pesquisa performativa.

\section{Pesquisa performativa e colaboração}

Em linhas gerais, a pesquisa performativa é uma tendência metodológica que vem sendo apontada por autores como HASEMAN (2006, 2015), BACON e MIDGELOW (2014, 2015), FERNANDES (2006, 2013, 2014, 2015b, 2018, 2015a), e propõe uma dissolução de fronteiras entre pesquisa, criação e realização. Nesse sentido, o fazer - no nosso caso, em arte - é o da pesquisa em si. A colaboração se associa a essa ideia também numa dissolução de fronteiras, mas no caso do fazer artístico, entre as instâncias do(s) compositor(es) e intérprete(s). Dessa forma, a criação em arte é pesquisa e é realizada colaborativamente por todos os envolvidos na ação.

Para Haseman (2015, p. 41), a ideia da pesquisa performativa se concretiza ao considerarmos que estamos diante de um momento crucial no desenvolvimento da pesquisa, onde as metodologias estabelecidas das pesquisas qualitativa e quantitativa enquadram o que é legítimo e aceitável, porém não conseguem satisfazer as necessidades de um número crescente de pesquisadores guiados-pela-prática. Há, então, a necessidade de novos modos de entender o processo de pesquisa que subentenda a complexidade do fazer não como parte de uma pesquisa, mas sim como a parte central do processo. Nesse caso, a (tradicional) escrita sobre a pesquisa é o modo de operar dos fazeres. Essa demanda vem sendo resolvida por artistas/pesquisadores na comunidade criativa sob denominações diversas, no entanto, o que emerge como unanimidade nos discursos é o fato da pesquisa-guiada-pela-prática ser intrinsecamente empírica, tornando-se concreta enquanto é realizada.

A pesquisa performativa vai além, também, de uma pesquisa artística, no que diz respeito ao papel da obra de arte (ou da prática abordada) no processo. é uma fronteira muito delicada de se perceber - porém, fundamental - pois muda o impacto de existência da prática no ato de pesquisar. Fernandes (2013, p. 25) esclarece que, no campo artístico, toda pesquisa relacionada à prática é artística, mas nem toda prática artística é pesquisa. Isso ocorre porque não se trata de usar/ler/estudar/etc. prática(s) já existente(s) como se fosse uma pesquisa, nem se trata de uma pesquisa feita necessariamente a partir de uma prática, numa reflexão sobre a mesma, nem tampouco de um processo de pesquisa que busca necessariamente gerar uma coreografia como resultado. Na pesquisa performativa há uma associação tão estreita entre pesquisa, criação e realização que todas se tornam uma coisa só: não há criação e realização sem pesquisa. De fato, é na prática que o conhecimento proposto acontece. 
Essa perspectiva de entendimento se relaciona com a teoria e prática do compor defendida por Paulo Lima (2012) que trata da composicionalidade como algo indissociável entre teoria e prática, afirmando que "a rigor, não existem práticas composicionais. Não se faz sentido representar o compor como se a teoria estivesse do lado de fora" (LIMA, 2012, p. 15). Nesse sentido, a composicionalidade viabiliza a criação de mundos a partir da interpenetração entre teoria e prática (LIMA, 2012, p. 15) colocando a composição (no caso musical) como uma interpretação crítica do mundo (LIMA, 2012, p. 25). Sob essa perspectiva, compor (música) é pesquisar.

A percepção e o entendimento dessa possibilidade podem revelar uma falsa situação de imobilidade interpretada como fragilidade, mas que justamente desvela a complexidade construída e sanada pelo processo que se torna metodologia enquanto se faz. As questões e hipóteses existem mais como ímpeto criativo do que determinantes e perpassam infindáveis trocas e movimentações. Essa instabilidade é justamente o que torna a pesquisa performativa rica e necessária. Esses questionamentos evidenciam a inevitável comparação dessa proposição com as já instauradas possibilidades de pesquisa amplamente praticadas na academia.

Nas pesquisas quantitativa e qualitativa, o projeto precisa fluir a partir de uma questão central de pesquisa ou declaração de problema, ou (em teoria fundamentada) a partir das experiências e entendimentos da população que está sendo pesquisada. A importância de identificar "o problema" ou "a questão" é evidente em instâncias diversas através da qual os candidatos são convidados a fornecer uma exposição clara do problema, com metas, objetivos e tantas outras questões de pesquisa a serem respondidas. Esses requisitos constituem a pesquisa-guiada-pelo-problema e podem ser atendidos através de ambas as metodologias, a qualitativa e quantitativa.

No entanto, muitos pesquisadores guiados-pela-prática não iniciam o projeto de pesquisa com a consciência de "um problema". Na verdade, eles podem ser levados por aquilo que é melhor descrito como "um entusiasmo da prática": algo que é emocionante, algo que pode ser desregrado, ou, de fato, algo que somente pode tornar-se possível conforme novas tecnologias ou redes permitam (mas das quais eles não podem estar certos). Pesquisadores guiados-pela-prática constroem pontos de partida empíricos a partir dos quais a prática segue. Eles tendem a "mergulhar", a começar a praticar para ver o que emerge. Eles reconhecem que o que emerge é individualista e idiossincrático. Isso não quer dizer que esses pesquisadores trabalham sem maiores agendas ou aspirações emancipatórias, mas eles evitam as limitações das correções de pequenos problemas e das exigências metodológicas rígidas em um primeiro momento de um projeto (HASEMAN, 2015, p. 44).

É justamente desse entusiasmo inicial, possível nessa proposta performativa, que a colaboração se fortalece. Isso ocorre pois, propor-se a equalizar desejos de vários artistas em 
uma só pesquisa (ou obra) é se colocar em aberto para a complexidade do processo por perspectivas diversas. Trabalhar de forma colaborativa é organizar os processos empíricos dos envolvidos em um caminho que seja coerente e unificado.

Processos colaborativos dessa natureza - em que artistas compartilham da criação de um caminho criativo, buscando, juntos equalizar suas individualidades em busca de coesão e coerência - reforçam o caráter distribuído da criatividade. Conceito inicialmente proposto por Clark e Doffman (2017), criatividade distribuída se refere ao fato de que todo processo artístico traz, em sua essência, um complexo criativo distribuído entre os participantes, de maneira horizontal. Apesar do conceito ter sido proposto na área de Música, a fim de questionar a notória distinção que existia entre compositores e i na música de tradição europeia dos séculos XIX e XX, criatividade distribuída vai, na verdade, muito além de uma querela entre músicos ditos teóricos e práticos, podendo evidentemente se estender para outros contextos artísticos interativos. Entretanto, quando, em processos interartísticos tais quais o que discutimos neste texto, partimos juntos a pesquisar guiados pela prática, parece-nos que falar sobre criatividade distribuída já não faz sentido algum. Afinal, outro tipo de criatividade, que não seja distribuída, nos parece difícil, senão impossível de conceber. Isso se deve provavelmente a questões relativas a autoria e controle das decisões criativas, que em Música, diferentemente de outras subáreas artísticas, historicamente têm sido colocadas, exclusivamente, nas mãos de compositores. Já quando tratamos de processos criativos na Dança, por exemplo, a simples ideia de que um indivíduo possa ser detentor único da criatividade, enquanto os demais a reproduzem para o público, abstendo-se de qualquer impulso criativo - embora reconheçamos que essa prática ainda ocorre comumente - parecenos obsoleta, senão incongruente.

Talvez uma concepção mais democrática, horizontal e distribuída da criatividade encontre, em colaborações interartísticas de pesquisa performativa, seu substrato ideal. Afinal, é aí que indivíduos de diferentes experiências artísticas, ao procurarem dialogar, propor, negociar, questionar, experimentar, e fazer escolhas juntos, definem, passo-a-passo, e de maneira compartilhada, o caminho de cada colaboração. Enquanto em Música o conceito de criatividade distribuída ainda possa soar reacionário, ele vem como uma alternativa ao "cenário de suposições que continuam a dar prioridade ao texto sobre a performance, e que celebra a autoanulação do performer ao interpretar aqueles textos" (DOFFMAN; CALVIN, 2017, p. 4).

Nesse contexto colaborativo, em que indivíduos de diversas áreas de experiência artística compartilham de um projeto, construindo juntos o caminho de um processo de criação, eles acabam aprofundando ainda mais seu conhecimento e experiência em suas próprias áreas. De fato, esse aprofundamento técnico (vertical), simultâneo ao compartilhar 
de conhecimentos (horizontal) - conceito proposto por John-Steiner (2000) como paradoxo da colaboração - nos parece estar no âmago da pesquisa performativa colaborativa.

Entendemos esse modelo como uma abordagem mais dinâmica para o fazer colaborativo, como já discutimos em outro texto recente (CARDASSI; BERTISSOLO, 2020, p. 7). Essa perspectiva considera a necessidade de aceitar a natureza flexível do processo criativo colaborativo no contexto da pesquisa performativa.

É importante esclarecer que adotamos a definição de Hayden e Windsor (2007, p. 33) para a interação entre compositores e performers (aqui estendida aos processos de criação interartes), como diretivos, interativos ou colaborativos. Segundo os autores, os processos diretivos são aqueles em que um músico encomenda uma obra musical, ou um grupo de dança encomenda uma música, por exemplo, sem um real nível de interação entre os envolvidos. Nos processos interativos, o compositor (ou o coreógrafo) se envolve mais diretamente nas negociações, por vezes realizando o que já referimos em outros textos como consultoria ou, como Fitch e Heyde (2007, p. 93) definem, os performers abrem suas "caixas de truques". Finalmente, os processos de fato colaborativos são aqueles em que as instâncias de decisão são compartilhadas entre os atores envolvidos na criação, de modo que todos os envolvidos se sentem efetivamente contemplados no processo.

O compositor Luke Styles descreve sua relação com performers de diferentes áreas de expertise (música, teatro e dança) da seguinte maneira:

Durante os estágios iniciais de criação de uma obra, acontece uma relação interativa e colaborativa com os performers (particularmente músicos), quando ideias são sugeridas e eu tomo decisões sobre elas em um ambiente criativo e, muitas vezes, experimental. Às vezes acontece, também, de eu deixar algumas decisões iniciais para os performers, sobre como desenvolver aspectos da música (tais como dinâmica, repetições e andamentos), e depois, juntamente com os músicos (e com os demais colaboradores) decidimos o que deve ser incluído na partitura. Dessa forma, uma partitura pode incluir as múltiplas decisões musicais tomadas durante um processo de composição e de colaboração, mas não todos os aspectos de uma performance final envolvendo elementos não-musicais.

Durante a fase de ensaios, a relação com performers tende a ser mais diretiva e interativa. Ainda assim haverá um diálogo com os performers sobre como interpretar e apresentar a obra, já que a interpretação precisa vir do performer, mas como um colaborador que pode ver a obra a partir de uma perspectiva de fora da performance em si, estou em uma posição de observar e ouvir aspectos da performance que talvez tenham passado desapercebidos pelo performer no ato da performance. Assim, é importante assumir uma relação diretiva com performers, nesse estágio, a fim de continuar a dar forma à obra desenvolvida colaborativamente, garantindo continuidade e coesão na obra com o um todo, enquanto performers se ocupam com o ato da performance. (STYLES, 2016, p. 10).

As colocações de Styles reforçam o caráter dinâmico e flexível de um processo criativo colaborativo, especialmente aqueles de natureza interartística. É certo que decisões são tomadas conjuntamente, mas isso não significa um absoluto contínuo de decisões compartilhadas durante todo o processo, nem invalida a existência - ou até mesmo a 
necessidade - de momentos onde as várias áreas de expertise se manifestam, individualmente, através até de contribuições de natureza diretiva, vertical. O caráter colaborativo de projetos tais como o discutido neste artigo reside no fato de que mesmo as decisões tomadas aparentemente de maneira vertical sejam discutidas, analisadas, questionadas, reformuladas, e ao final, acatadas e desenvolvidas pelos participantes. Só assim um processo criativo pode ser de fato colaborativo, em que os processos intuitivos e empíricos dos artistas envolvidos se entrelaçam de forma a constituir um todo orgânico e coerente, onde todos se sentem representados.

\section{Estado de prontidão}

No processo da criação colaborativa, ocorre uma fricção de saberes multidirecional a partir da qual algo se constrói. Foi na busca por esse algo que nos propusemos encarar o conceito do Estado de Prontidão. Essa escolha ocorreu também por demanda temporal da ocorrência do processo de pesquisa de doutorado de um dos artistas (Lia Sfoggia) mas também pela incumbência conceitual à que se refere esse entendimento: a ideia de imprevisibilidade em relação ao futuro, o fato de nunca sabermos o que pode acontecer no instante seguinte, a possibilidade de sofrer um ataque a qualquer momento, a desconfiança. Tudo isso propicia a necessidade de manter-se num constante estado corporal de prontidão para agir, e todos esses aspectos emanam pressupostos que interessam artisticamente os artistas envolvidos.

No contexto da capoeira, ao entrar na roda há sempre um momento de lacuna. Mesmo que conheçamos o oponente, nunca podemos prever como aquele jogo se iniciará e como a pessoa recriará sua resposta de movimento no diálogo corporal dentro da roda. Nesse sentido, o Estado de Prontidão se refere à necessidade do capoeira manter-se alerta e disponível, e como esse comportamento influencia o modo de se mover. Um bom capoeira, para além de uma vasta gama de golpes, precisa saber acessar esse estado, pois se não souber como e quando aplicar quaisquer movimentos, toda a maestria e virtuosidade se fragilizará frente à previsibilidade de sua resposta motora. No processo de ensino e aprendizagem da capoeira, a prática - especialmente na experiência do jogo que ocorre nas rodas - viabiliza a apropriação corporal da percepção da necessidade de saber sair e entrar na ação, retomar e propor movimentos, estar sempre pronto para agir. Esse estado é muito nítido ao observar, por exemplo, os mestres mais experientes jogando. Muitas vezes a habilidade corporal os trai por já não conseguirem executar movimentos complexos com perfeição estética, mas a capacidade de ver o jogo e responder com prontidão tende a superar a virtuosidade e se estender à vida cotidiana.

Nesse sentido, é interessante observar a dinâmica da roda e como acontece a resolução dos desafios corporais. Há um aprendizado muito rico nessa observação, mas que 
invariavelmente nos levava a um lugar de não definição, porque é impossível traçar uma dinâmica da causa e efeito, vista a complexidade dessa relação. Por esse viés, os melhores capoeiristas são primeiramente os que dominam esse Estado de Prontidão, que resolvem os desafios e permanecem abertos ao jogo. O treino, a aquisição de movimentos mais plurais e todo investimento na ampliação e efetividade dos movimentos é necessário e bem-vindo, no entanto, sem a percepção do momento adequado para proposição, provavelmente iremos de encontro ao conceito de Economia de Meios, que justamente evidencia a necessidade de ponderar, para além do quando e como (Estado de Prontidão), o quanto (Economia de Meios) devemos apresentar ${ }^{1}$. Mestre $\mathrm{Nenel}^{2}$ afirma com frequência que a capoeira é um modo de vida que vai além dos treinos e jogos. Esses dois conceitos alimentam muito essa assertiva quando percebemos a prudência e agilidade de raciocínio a que se referem, não apenas no contexto da capoeira, mas também no cotidiano do capoeirista. Nesse sentido, a Economia de Meios depende do Estado de Prontidão (e vice-versa) para se exercer. é preciso manterse aberto e atento para corporificar esse conceito na medida do necessário.

No processo de pesquisa de doutoramento de Sfoggia, foram realizados dois laboratórios ${ }^{3}$ de observação e análise de movimento dentro do contexto da capoeira, através dos quais podemos destacar aspectos que emergiram como desdobramento relacionados ao Sistema Laban Bartenieff de Análise de Movimento. Para identificação e desenvolvimento do Estado de Prontidão, algumas nuances foram percebidas nos laboratórios de imagem e movimento. Para esse ponto de vista, as fotografias indicam a ação resultante dos artifícios de movimento escolhidos pelos capoeiristas ao solucionar seu desafio quando, por exemplo, percebemos a alternância de base dos pés/mãos na continuidade da ação que estava sendo executada. é nesse sentido que afirmo que não há uma única solução adequada, pois a decisão é mediada por uma conjuntura de inúmeros fatores em diálogo, desde as possibilidades corporais do capoeirista até todas as variáveis do contexto. $O$ ato de experienciar o momento encaminha essa ação em relação ao contexto. A cada momento os corpos (não só) podem (como devem) assumir novas atitudes de resolução e, justamente essa capacidade de variabilidade, é o que vai enriquecer o jogo.

\footnotetext{
${ }^{1}$ É importante salientar que a tese de Lia Sfoggia, que propõe o conceito do Estado de Prontidão, também apresenta outros dois conceitos: a Economia de Meios e o Equilíbrio Dinâmico. Todos os três são perspectivas independentes, mas constroem-se de modo correlacionado a partir da observação e análise da Capoeira Regional.

${ }^{2}$ Mestre Nenel (Manoel Nascimento Machado) é filho de Mestre Bimba (Manoel dos Reis Machado 1900-1974), criador da Capoeira Regional. Atualmente, desenvolve o seu trabalho com a capoeira e viabiliza as atividades da Filhos de Bimba Escola de Capoeira (FBEC) e da Fundação Mestre Bimba (FUMEB).

${ }^{3}$ A tese apresenta laboratórios de duas naturezas: uma sessão de coleta de imagens e sessões de Movimento Autêntico. Foi através dessas duas possibilidades que construiu-se um reconhecimento da Capoeira Regional através da experiência pessoal. esses processos estão detalhadamente descritos na tese.
} 
Ao avançarmos em relação ao laboratório de imagem e partirmos para análise do laboratório de movimento, desenvolvido através das sessões de Movimento Autêntico ${ }^{4}$, destacamos os pontos observados que nos levaram ao conceito do Equilíbrio Dinâmico, que foi tratado e desenvolvido anteriormente: as transferências de peso e continuidade para, avançando na análise, chegar no entendimento da Pausa Dinâmica. Dentro do Sistema Laban/Bartenieff, o Princípio da Dinâmica Postural (FERNANDES, 2006, p. 54) aponta um equilíbrio postural em estado de continuidade que nos coloca aptos para mudança.

Nesse sentido, uma aparente pausa (o corpo parado no espaço) pode sustentar uma imobilidade que mantém uma organização interna viva e capaz de deixar essa inércia aparente e mover-se. Ao contrário de abandonar o movimento, esse estado seria uma Pausa Dinâmica; e é uma construção corporal muito evidente e frequente dentro do jogo da capoeira. A ideia transita entre o conceito de Equilíbrio Dinâmico (até mesmo pela ideia de dinamicidade evidente em suas nomenclaturas) e o Estado de Prontidão, no sentido de que, enquanto o primeiro aponta a dinamicidade do movimento interno do corpo, o segundo depende dessa dinamicidade para disparar as reações necessárias. É como uma correlação que se baseia justamente na capacidade do corpo de construir essa condição que, ao mesmo tempo em que depende da continuidade, propicia a prontidão.

A negaça, através da qual o capoeira transita e constrói seu diálogo com o movimento do outro, perpassa por essa pausa constantemente, assim como a variabilidade de fatores expressivos que se alternam entre livre e controlado, forte e leve, acelerado e desacelerado, direto e indireto. O Estado de Prontidão não consegue traçar uma correspondência com fatores específicos, pois depende justamente da variabilidade para se concretizar e multiplicar sua capacidade de surpreender o oponente. Ao tentar identificar padrões de análise para esse conceito, chegamos justamente no lado oposto dessa intencionalidade, pois a capacidade de evitar quaisquer padrões é justamente o que atribui maior efetividade para esse conceito.

Pensando nessas nuances do movimento e do estado do corpo na capoeira, nunca há essa pausa que se refere ao abandono do movimento e da energia de estar em jogo. Os momentos que aparentam uma interrupção de movimento, na verdade guardam no corpo uma propulsão interna que fica evidente na capacidade de resolução de resposta imediata, e essa capacidade é a base do conceito do Estado de Prontidão. Para efetivação dessa energia constante, percebemos a ênfase em dois Princípios de Movimento Bartenieff, que são o Suporte Muscular Interno e a Intenção Espacial (FERNANDES, 2006).

Esses dois princípios são caminhos pelos quais o corpo se coloca disponível para a constante e desejada resolução de desafios. O Suporte Muscular Interno se baseia no uso da

\footnotetext{
${ }^{4}$ O Movimento Autêntico é um método de exploração corporal criado por Mary Whitehouse para busca do que Laban chama de Antrieb ou a pulsão de movimento.
} 
musculatura mais profunda para estabilização e suporte das ações motoras e perpassa por todos os conceitos. No entanto, no que diz respeito ao Estado de Prontidão, faz-se fundamental no sentido de que, ao delegar à musculatura interna a tarefa de dar suporte ao corpo, abre-se espaço para que a musculatura mais superficial possa complementar a resposta aos desafios. Enquanto o Suporte Muscular Interno mantém o corpo disponível e em movimento, no tocante da capoeira através da ginga por exemplo, a musculatura mais superficial pode trazer para a ação o necessário para dar conta dos detalhes da situação que o específico espaço-tempo de seu acontecimento demanda.

O uso dos músculos internos para estabilização e suporte permite o destensionamento da musculatura superficial e facilita o movimento e a expressão corporal. Ou seja, liberados da função de suporte, inapropriadamente atribuída, os músculos superficiais podem ser usados nas diversas nuances da expressão. (FERNANDES, 2006, p. 54).

É através do movimento viabilizado pela musculatura mais superficial que destacamos a Intenção Espacial, pois é através desse Princípio que as particularidades da situação se solucionam e são projetadas no jogo. Essa intenção não se refere, necessariamente, ao foco do movimento em relação ao fator expressivo espaço ${ }^{5}$, mas de sua projeção a partir do corpo no Espaço (físico/contextual), relacionando-se prioritariamente com a Categoria Espaço ${ }^{6} \mathrm{e}$ sua ocupação e mobilidade de acordo com a cinesfera dos praticantes.

Este princípio implica no tônus muscular das partes que, ao moverem-se, projetamse no Espaço. Não é necessário que se direcionem para este ou aquele ponto no Espaço, mas que apresentem em si, enquanto Corpo, uma intenção de prolongarem-se para o Espaço, mesmo que em aparente repouso. (FERNANDES, 2006, p. 69).

Por essa construção conceitual, ao que se relaciona com a pesquisa de Bertissolo (2013) através de m’bolumbümba: entre o corpo e berimbau, refere-se ao conceito de surpreendibilidade. Trata-se de um neologismo que se refere à capacidade de surpreender. Talvez esse seja um dos principais elementos da Capoeira Regional. Todo o capoeirista entende a importância da capacidade de surpreender. Na Capoeira Regional, a eficácia em surpreender o oponente reside no ato de derrubá-lo, ou ao menos, desequilibrá-lo. O equilíbrio, o ponto de estabilidade do capoeira, está no chão. A surpreendibilidade na Capoeira Regional é a quebra de um equilíbrio, e o capoeira deve estar sempre pronto para se reequilibrar. Nesse sentido, há expectativa em observar e gerar movimento, seja no

\footnotetext{
${ }^{5}$ Espaço aqui se refere à Categoria Expressividade e seu fator espaço. Para maiores informações, consulte Fernandes (2006).

${ }^{6}$ O Sistema Laban/Bartenieff se divide em quatro grandes Categorias: Corpo, Expressividade, Forma e Espaço. A associação dessas quatro categorias se refere à Corêutica. Para maiores informações, consulte Fernandes (2006) .
} 
entendimento da surpreendibilidade, seja para o Estado de Prontidão. Esse constante estado de mudança e disponibilidade é o ponto de diálogo entre esses conceitos.

O Estado de Prontidão, ao se colocar como um fruto da relação do espaço-tempo de cada jogo em diálogo com os corpos (complexos) que se entremeiam em ações corporais, assume a impossibilidade de traçar parâmetros concretos de análise de movimento, pois depende do seu acontecimento. Nesse sentido, o entendimento desse conceito perpassa por modos de organização corporal (Categoria Corpo no Sistema Laban/Bartenieff), mais do que pela análise de Expressividade, de Forma ou Espaço. São as possibilidades dos corpos que estão em jogo que alimentam essa conceituação, para além do modo como enxergamos o movimento resultante dessa organização.

\section{Estado de Prontidão}

\begin{tabular}{l|l}
\hline \hline \multicolumn{1}{c|}{ Elementos do conceito } & Desdobramentos em análise de movimento \\
\hline - manter-se alerta e disponível & $\begin{array}{l}\text { - pausa dinâmica } \\
\text { - imprevisibilidade }\end{array}$ \\
- $\begin{array}{l}\text { capacidade de resolução de } \\
\text { desafios corporais }\end{array}$ & $\begin{array}{l}\text { - Intenção Espacialidades de fatores expressivos } \\
\text { - Categoria Espaço }\end{array}$ \\
\end{tabular}

Figura 1 - Quadro resumo sobre o conceito de Estado de Prontidão

\section{Os processos de Converse}

Converse é uma obra colaborativa que apresenta dois vídeos, acompanhados de performance, música eletrônica e execução de piano ao vivo composta conjuntamente baseada no eixo/conceito do Estado de Prontidão. O trabalho foi estreado em 10 de setembro de 2018, no Salão Nobre da Reitoria da UFBA7 ${ }^{7}$, em ocasião do Seminário de Criação Colaborativa, evento idealizado e executado por Guilherme Bertissolo e Luciane Cardassi no âmbito do Programa de Pós-Graduação em Música da UFBA. Para o processo de criação, destacamos a composição não hierarquizada, a imprevisibilidade das proposições e desdobramentos, a escolha dos vídeos que contam com processamento em tempo real e captação e projeção ao vivo, além do jogo entre som e movimento. Esses foram parâmetros desdobrados a partir do Estado de Prontidão que, no contexto dessa obra, reverberou no

\footnotetext{
${ }^{7}$ Um registro da obra pode ser assistido em www.youtube.com/watch? $v=4 j \_k K p B m h C c \& t=3 s$.
} 
sentido de propor um estado de alerta e disponibilidade, a imprevisibilidade e a capacidade de resolução de desafios corporais.

A ideia inicial desse trabalho surgiu do nosso desejo de partilhar o palco. Luciane foi Professora Visitante da Escola de Música da UFBA (de fevereiro de 2018 a fevereiro de 2020) e esteve, juntamente com Guilherme, ministrando a atividade Ateliê de Composição e Performance Contemporânea, onde tratam justamente do ensino, criação, discussão e análise de obras colaborativas (CARDASSI; BERTISSOLO, 2020). Perante o ímpeto da criação colaborativa, aproveitamos a oportunidade para desenvolver um dos conceitos inferidos na pesquisa de Lia Sfoggia, a qual propôs que trabalhássemos com o Estado de Prontidão. Assim, nos dispomos, coletivamente, a desenvolver esse trabalho.

Nos primeiros encontros que fizemos, em uma sala de aula da Escola de Música da UFBA, conversamos sobre o conceito e fomos, a partir dessa ideia, pensando em possibilidades para experimentação. Iniciamos com proposições de caráter bastante aberto e experimental, onde Luciane e Guilherme dialogavam produzindo sons e as primeiras germinações a serem desenvolvidas em partituras, enquanto Lia observava e registrava em imagens. Já nos primeiros contatos, emergiu a demanda de trazer mais informação visual para esse trabalho. Assim, no desenrolar dos encontros, Lia foi se incumbindo de explorar, através de fotografia e vídeos, o trabalho ao piano.

Desses ensaios, aos poucos a composição da música foi se consolidando e a pesquisa visual foi se concretizando num banco de 23 imagens estáticas (figura 2) e vários pequenos trechos de vídeo que foram editados em 3 pequenos vídeos (figura 3$)^{8}$. Essas imagens, tanto em fotografia quanto em vídeo, foram sendo apreciadas no processo dos ensaios, onde observamos a relação do toque do corpo no piano, através das mãos e pés e seu reflexo em som; as possibilidades em relação aos martelos de dentro da estrutura do piano, que ao serem tocados ou preparados com algum material, produziam novas sonoridades; as tentativas de acertar a exata tecla que estava escrita na partitura, em contraponto com os parâmetros que podiam apresentar variações.

\footnotetext{
${ }^{8}$ Disponíveis em youtu.be/KTEEOHAiebc, youtu.be/W-JGMCgsZRg e youtu.be/1pyRgGdk8xk.
} 


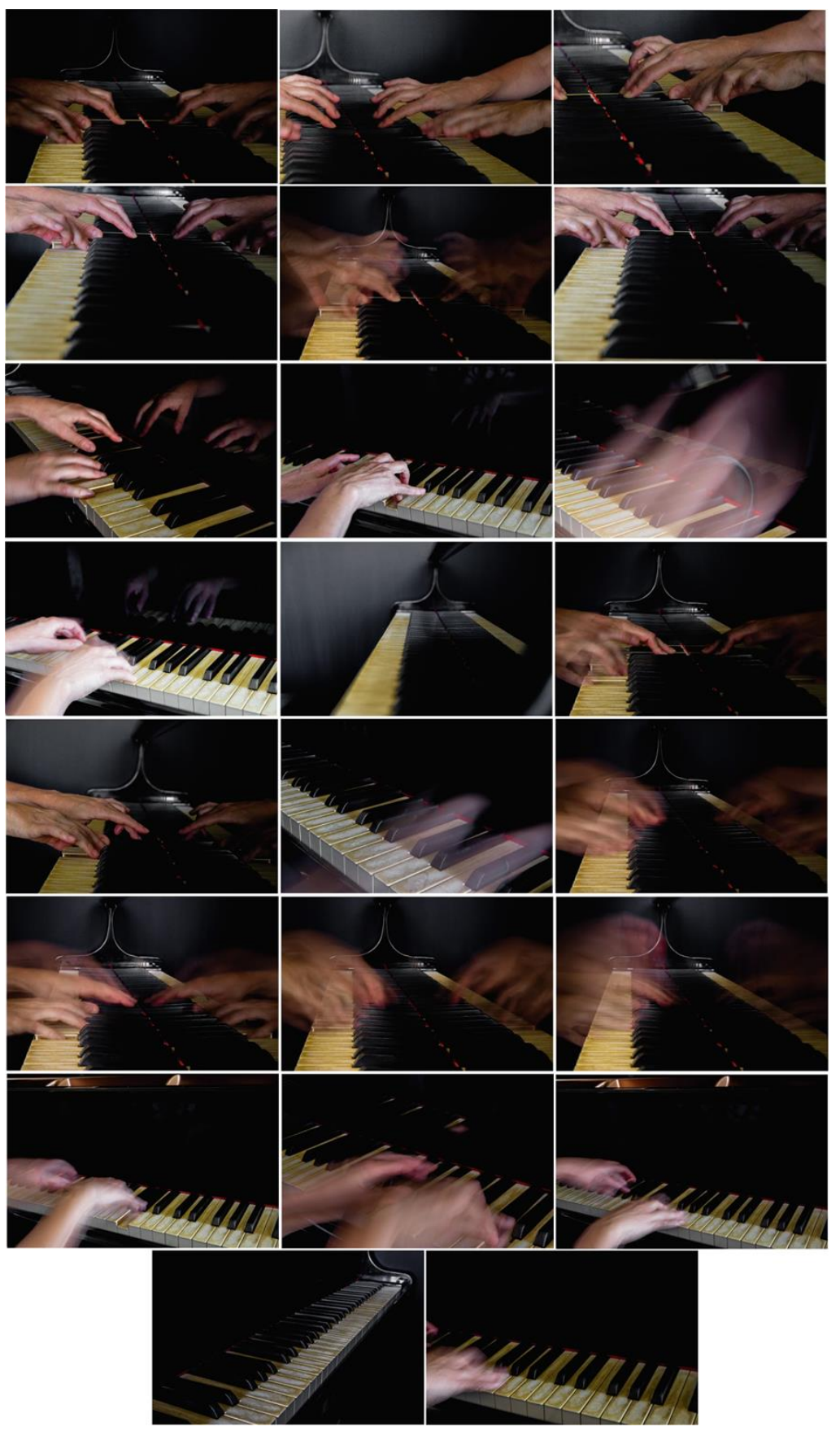

Figura 2 - Banco de Imagens para o processamento em tempo real em Converse

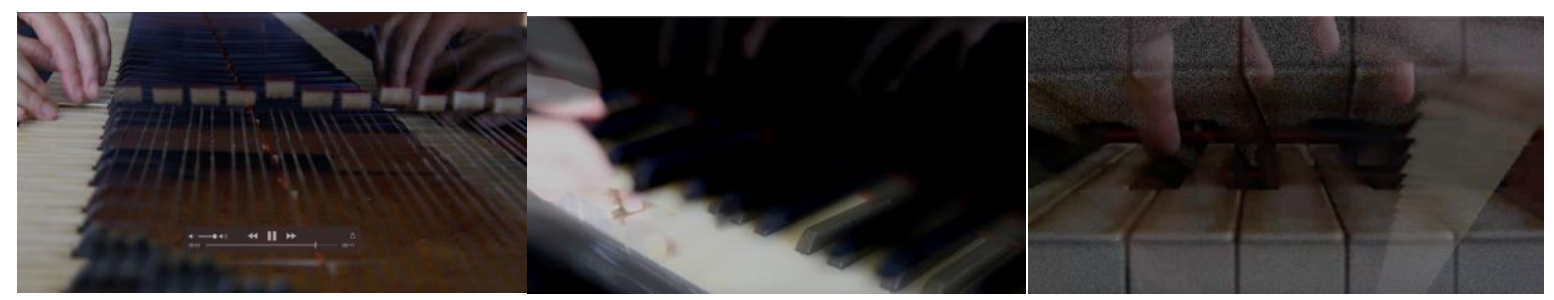

Figura 3 - Vídeos para processamento em tempo real em Converse 
Os pequenos vídeos são resultantes de um entremeamento de imagens que ora se encontram, ora variam em tempo e posição. São muitas possibilidades, que forneceram material para um banco de imagens que, no decorrer da performance do trabalho, são sorteados no vídeo produzido ao vivo, com processamento em tempo real através de programação no software Pure Data ${ }^{9}$, programado por Guilherme (figura 4). O patch realiza processamento em tempo real de som (parte esquerda da figura) e vídeo (parte direita), simultaneamente.

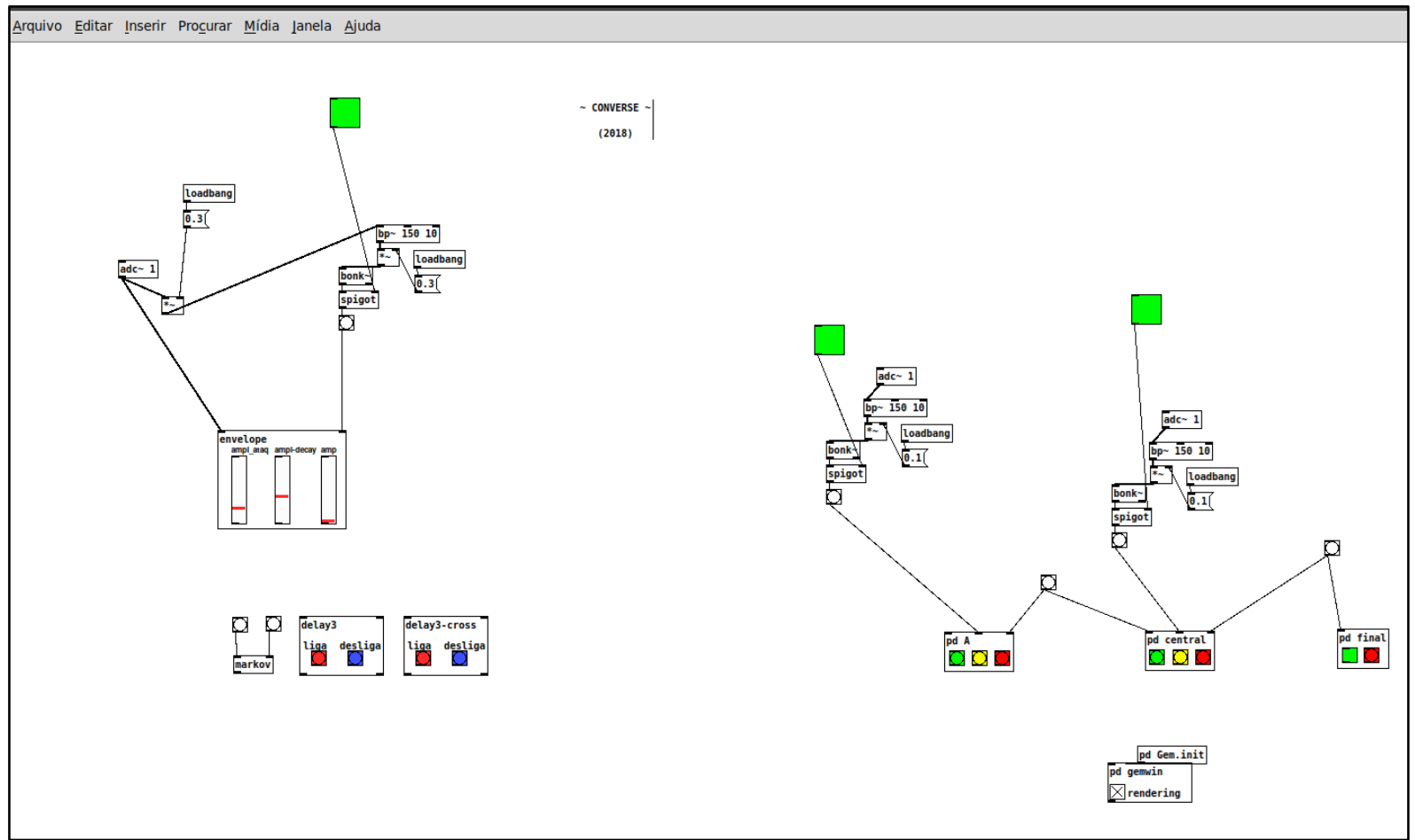

Figura 4 - Patch PureData usado em Converse

Os sons produzidos são capturados por um microfone condensador posicionado nas cordas do piano. No caso dessa peça, as respostas do computador ao processamento são aleatórias e, basicamente, realizadas em quatro processos, sucessivos ou simultâneos: 1 uma amplificação brusca das ressonâncias dos acordes tocados ao piano; 2 - um delay que multiplica os ataques; 3 - um processo que o compositor chama delay espectral, que utiliza

\footnotetext{
${ }^{9}$ Pure Data, ou Pd, é uma linguagem de programação visual orientada ao objeto, desenvolvida por Miller Puckette na década de 1990, para criação de música eletrônica, música electroacústica, música interativa, e trabalhos multimídia. Maiores informações no site https:puredata.info.
} 
informações de um banco de dados de durações baseado em um repertório de músicas previamente analisadas; e 4 - um processo aleatório de ressíntese, que transforma (baseado em probabilidades definidas) o som do piano e o transpõe, mudando a velocidade e a textura em tempo real.

Partindo desse ponto, já tínhamos a performance ao vivo do piano (que vinha sendo ensaiada e trabalhada nos encontros na Escola de Música da UFBA), bem como vídeos e imagens processados em tempo real para dialogar em cena. Durante o processo de ensaio da música e edição dos materiais audiovisuais, começamos a entender o todo do trabalho de modo que concordamos com uma performance de movimento (Lia) ao vivo em diálogo com o piano, além dos vídeos. Foi partindo da edição desses vídeos que, a partir de diálogos entre os colaboradores, percebemos o desejo de trabalhar com as variações de tempo, que acabaram embasando o jogo do piano e da performance de movimento ao vivo. O layout do palco foi determinado para o espaço que seria a estreia, o Salão Nobre da Reitoria da UFBA, considerando sua estrutura e as necessidades a serem privilegiadas na apresentação. Fomos estudando o espaço (figura 5) de uma forma onde houvesse um jogo de projeção, luz e sombras entre a performer e a pianista, para além do vídeo produzido em tempo real. Conseguimos chegar a um formato de distribuição, testado na semana anterior à estreia em uma visita técnica ao espaço, mas que só se efetivou no dia da montagem, com a afinação dos vídeos, piano e localização da performance (figura 6): Lia ficou centralizada no palco com os projetores apontados para ela, formando sombra nas paredes ovaladas da Reitoria; à direita, Luciane dividia com Lia as sombras formadas no vídeo processado em tempo real e, projetado à esquerda, tínhamos outro vídeo, oriundo da captação ao vivo da minha imagem, com a câmera ${ }^{10}$ disposta na frente de Lia. Aqui, um novo desdobramento do Estado de Prontidão, visto que as definições espaciais só se tornaram factíveis ao considerar o espaço e tudo que nele estava presente. Antes disso, não foi possível testar qual a abertura de imagem dos projetores que estavam disponíveis, onde poderíamos projetar ou como afinar os equipamentos. Prevemos algumas situações (como quem treina os golpes da capoeira no dia a dia), mas só na dinâmica do dia da apresentação (ou da roda de capoeira), é que pudemos coordenar as informações conforme a demanda daquele espaço-tempo. Por fim, não conseguimos viabilizar um modo de disposição onde Luciane e Lia conseguissem se enxergar, apenas Lia conseguia ver Luciane, e as sombras delas eram refletidas na parede.

\footnotetext{
${ }^{10}$ Uma câmera GoPro Hero4 Silver.
} 


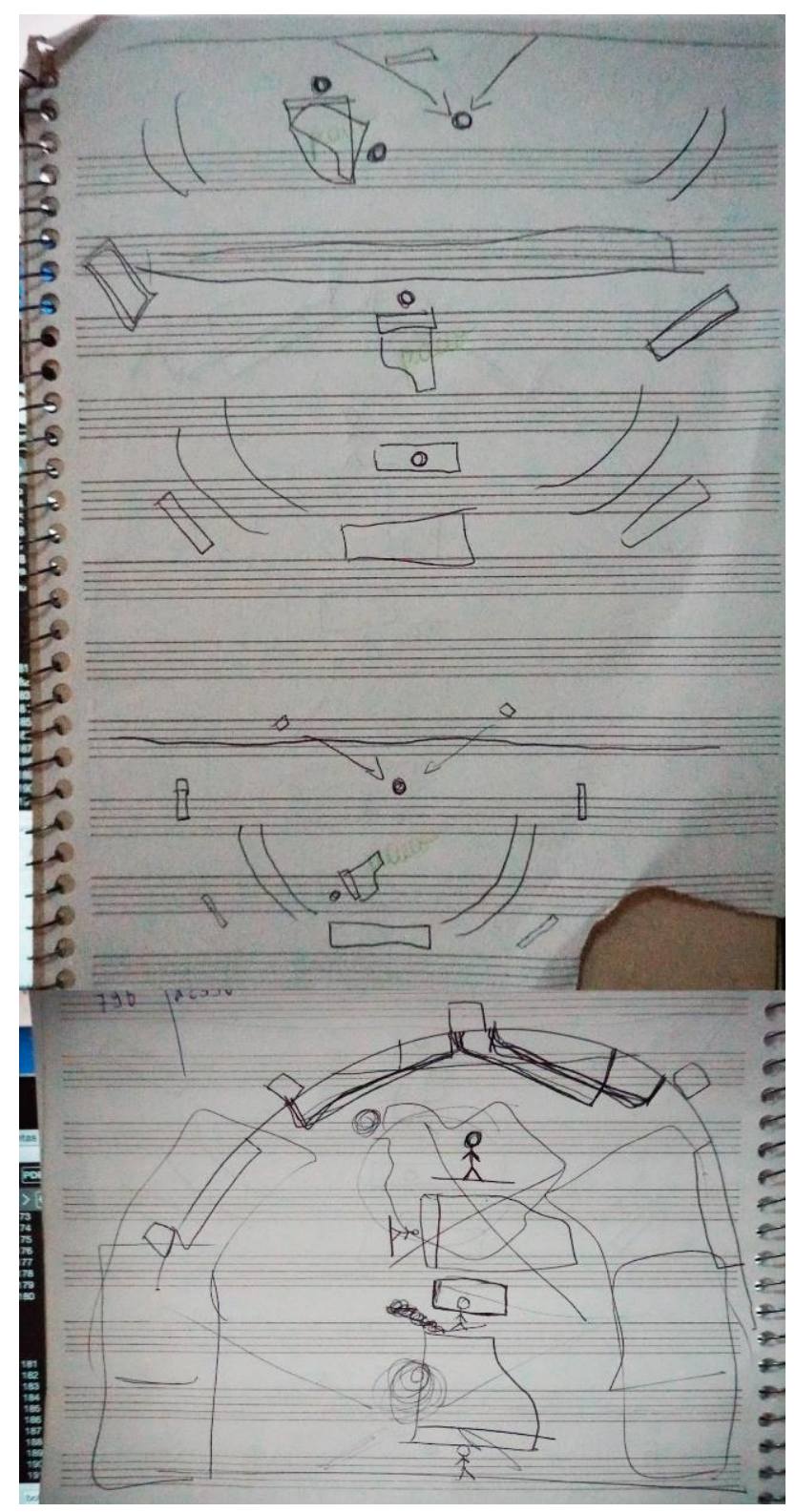

Figura 5 - Rascunhos para decisão do layout do palco na Reitoria da UFBA para Converse

O vídeo que é processado se divide em 3 partes, correspondentes a cada uma das seções da peça. A primeira delas é uma esfera branca que cresce pouco a pouco, o que durante o processo, emergiu da necessidade de iluminar a performance no palco. Essa esfera também sofre mudança aleatória na sua opacidade em resposta a alguns dos ataques do piano. Nessa etapa do vídeo, a interação com movimento foi mais sutil, apenas com as sombras se entrecruzando como se apresentassem a performer e a pianista, num jogo de aparecer e esvanecer junto à opacidade da iluminação gerada pelo vídeo. $\mathrm{Na}$ segunda seção, essa esfera se multiplica e 6 círculos passam a girar aleatoriamente, crescendo também pouco a pouco. Nessa etapa o computador sorteia imagens (do banco apresentado na figura 2) que são plotadas como flashes em cada um dos círculos, também 
aleatoriamente. Pouco a pouco esses flashes vão ficando mais recorrentes, até que ocupam quase toda a tela. Esse é o momento onde mais intensamente há um jogo entre os movimentos e suas variações de velocidade e intensidade. Finalmente, a terceira seção apresenta os 3 vídeos produzidos durante o processo (figura 3). O computador sorteia em que ponto cada vídeo será iniciado, se será mostrado em preto e branco ou colorido, e o tempo que irá durar. Dessa forma, as possibilidades de combinação são múltiplas. Nesse momento, na performance de movimento, retiro-me da frente do aparelho que projeta a imagem do vídeo em processamento e, mais ao final da peça, finalizo com uma interferência de sombras próximas à lente do projetor, jogando com a possibilidade de esconder e mostrar partes do vídeo, que nesse momento ocupa boa parte da tela.

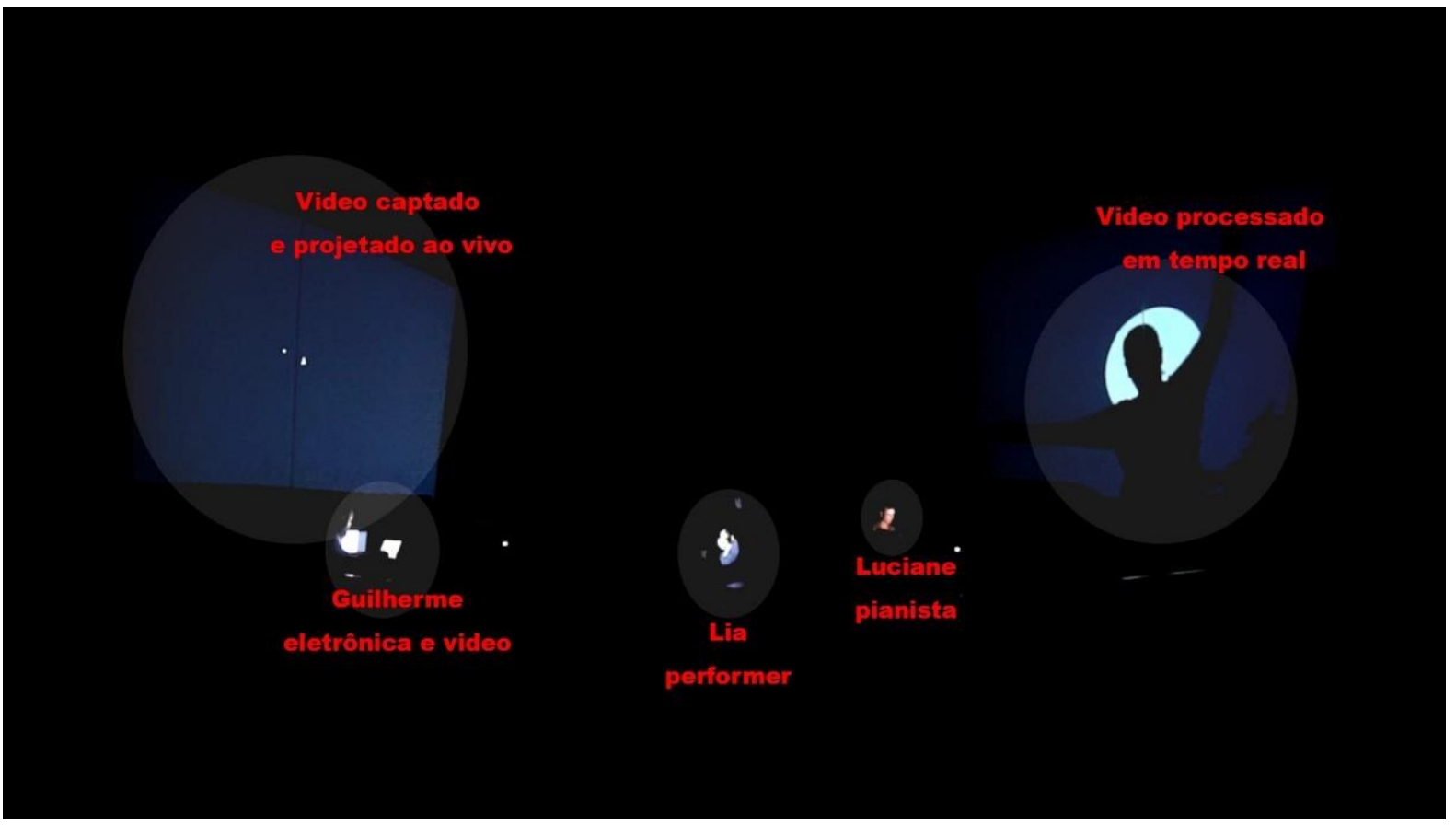

Figura 6 - Organização do palco utilizado para Reitoria da UFBA na estreia de Converse

As trocas sobre os conceitos permearam as decisões e sempre que era necessário algum encaminhamento, retornávamos ao entendimento do Estado de Prontidão. Desde a distribuição das ações cênicas no palco (que variam conforme o espaço de apresentação), até as experimentações com a música e o jogo entre a performer e a pianista. Para essa etapa de interação entre Lia e Luciane, no que concerne a performance de dança, Lia foi experimentado como dialogar com as nuances da música que seriam variáveis e de pronto relatou sua percepção de que a composição musical abria uma brecha para variações de tempo nas execuções. Considerando as demandas para delimitação do layout da peça, consideramos a necessidade de trazer uma performance que não tivesse grandes deslocamentos e assim, 
decidimos que Lia trabalharia com movimentos de tronco e braços com uma base fixa. Remetendo ao m'bolumbümba: entre o corpo e o berimbau, houve o resgate do estudo de movimentos da Sequência de Bimba ${ }^{11}$ feita com braços em jogo com sombras (o que parecia se relacionar bastante com o que estava sendo desenhado até então) e, partindo dessa experimentação, testamos o jogo de interpretar esses movimentos em relação ao som. A partir daí, tivemos a ideia de abrir a possibilidade de Luciane e Lia jogarem durante a obra, num diálogo de movimento em que o tempo da música (figura 7) interferia no movimento de modo a sugerir variação de peso (forte e leve) e tempo (acelerado e desacelerado).
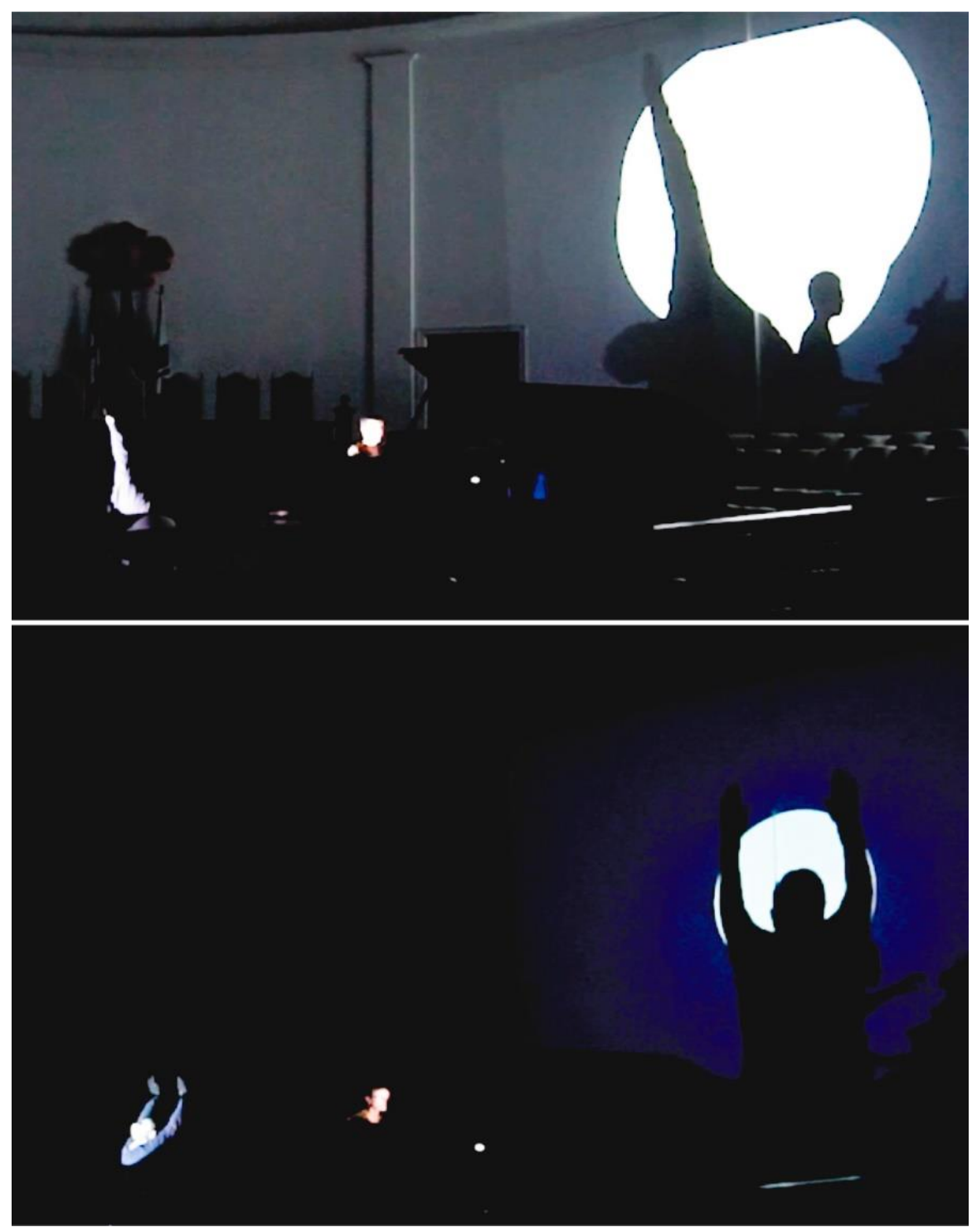

Figura 7 - Registro dos jogos entre movimento, luz/sombra e piano, durante a apresentação de Converse na Reitoria

\footnotetext{
${ }^{11}$ Para maiores informações sobre a Sequência de Bimba, sugiro consulta do livro Bimba: um século da Regional (MESTRE NENEL, 2018, p. 49).
} 
Durante a elaboração da tese, pouco tempo depois da estreia da obra Converse, no ensejo de captar as impressões dos colaboradores, Lia solicitou depoimentos por escrito que subsidiassem a discussão sobre o processo artístico colaborativo. As percepções sobre esses encaminhamentos se evidenciam nesses relatos, que, pelo frescor e teor confessional, entendemos que devem aparecer no formato original nesse artigo. Enquanto Guilherme traçou uma relação intensa com a surpreendibilidade - conceito proposto e discutido por ele em sua tese de doutorado (BERTISSOLO, 2013), discutido na seção 3 -, Luciane discorre sobre a sensação de mobilidade que permeou desde os ensaios até a organização do trabalho em cena.

Guilherme, na ocasião, trouxe o conceito para a composição musical (a figura 8 apresenta alguns dos rascunhos produzidos no processo colaborativo), perpassando o piano e a eletrônica. Numa composição dinâmica, baseada numa troca colaborativa, provocando reações entre a performer e a pianista, numa conversa multidimensional:

$\mathrm{Na}$ obra Converse o conceito esteve presente desde a primeira ideia. Creio que a imprevisibilidade foi um dos principais elementos, permitindo um diálogo entre os processos eletrônicos de som e vídeo, a pianista e a performer. Creio que o Estado de Prontidão é um elemento chave para entender o processo colaborativo da obra, considerando as decisões que são tomadas durante a performance pelos participantes, incluindo os processos realizados em tempo real pelo computador, e como cada um reage às diferentes a essas decisões. O emaranhado de diálogos que decorrem dessas escolhas e desdobramentos durante a experiência da performance são decorrentes da capacidade perceptiva dos colaboradores e permitiram um processo criativo repleto de significados (Guilherme Bertissolo - Depoimento por escrito, disponível na íntegra em SFOGGIA, 2019). 


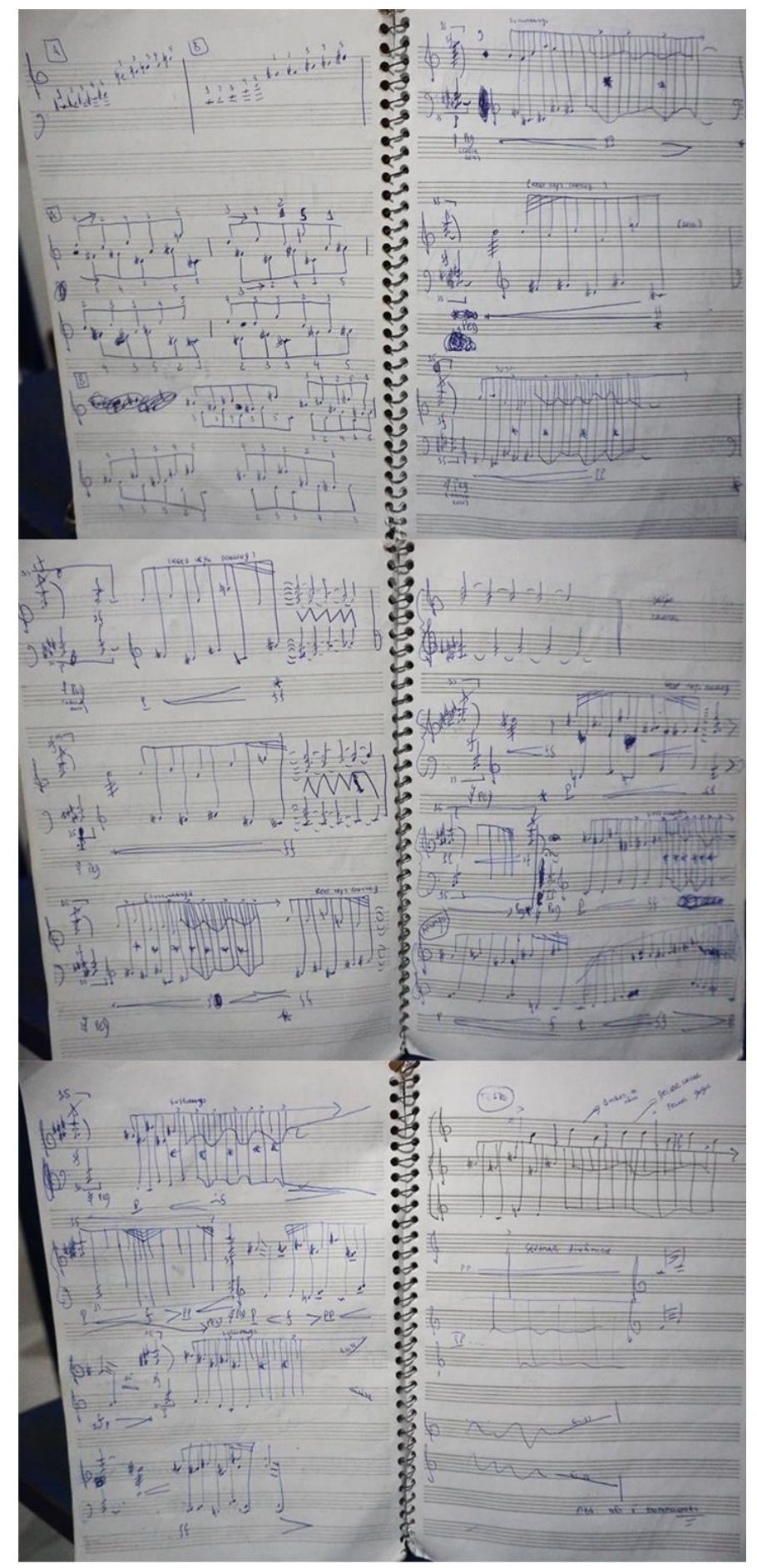

Figura 8 - Rascunhos: processo de composição da música para Converse

Já Luciane, além de citar esse processo colaborativo em relação à música, considerou mais intensamente nossa interação em cena. Nosso desejo inicial era um jogo entre som e movimento e, no contexto da estreia, foi perfeitamente possível no que diz respeito à escuta da música e resposta corporal no palco. No entanto, ainda fica o desejo de intensificar as possibilidades de Luciane responder aos movimentos para que o desafio seja uma via de mão 
dupla. Ainda assim, conforme o relato posterior das pessoas que puderam assistir à performance, a interação das sombras dos movimentos de Lia gerou um diálogo interessante com as sombras resultantes do corpo da pianista. A partir dessa experiência, Luciane destaca a natureza não hierárquica ocorrida no nosso processo de criação, que fortalece e muito o Estado de Prontidão por nós desejado:

Gostaria de concluir dizendo que Estado de Prontidão é também uma metáfora de um tipo de colaboração que envolve interação entre os colaboradores em um nível mais profundo, mais visceral, do que normalmente acontece (ao menos na música de concerto contemporânea). Converse, a meu ver, é um ótimo exemplo do que Hayden e Windsor (2007) chamam de criação verdadeiramente colaborativa, que não é apenas diretiva (prescrita por uma partitura ou script) ou interativa (em que o contato entre colaboradores se deu para discutir o que era possível ou não). Nesse terceiro nível, mais profundo, de colaboração "colaborativa", existe parceria na tomada de decisões, sem hierarquia de papéis, e na autoria do trabalho final, que não é visto apenas como originário de um autor, mas, neste caso, de três. (Luciane Cardassi Depoimento por escrito, disponível na íntegra em SFOGGIA, 2019).

Sob o ponto de vista da obra, é importante mencionar quatro aspectos principais que nortearam os processos e acabaram se consolidando em Converse: a noção de gesto, o tema de contenção/expansão, complementaridade/contrastes e as ideias de expectativa/surpresa. Sob o ponto de vista dos gestos ${ }^{12}$, a ideia inicial das sessões de colaboração foi explorar gestos no piano com acentos aleatórios (ver rascunhos na Figura 8), que acabaram por obedecer uma "inteligência dos dedos", uma vez que as notas a serem acentuadas dependem do próprio ato da performance. Esse elemento performativo acabou sendo uma das ideias desdobradas ao longo da peça, uma vez que esses gestos acabaram se repetindo, alternados com os ataques súbitos realizados pela pianista nos extremos do piano. Essa imprevisibilidade dos acentos e ataques foi um dos principais temas explorados na performance, potencializadas pelos processos aleatórios da eletrônica e do vídeo. As interações entre luzes e sombras, bem como os padrões de exploração das cinesferas mais amplas, foram diretamente influenciadas por esse elemento, manifestando uma forte relação com o conceito de Estado de Prontidão.

Esta noção de gesto foi desenvolvida ao longo da performance com a ideia de contenção/expansão. No começo de Converse, tanto os gestos da pianista quando da performer estão contidos, sendo pouco a pouco expandidos ao longo do tempo. Os gestos da pianista vão ganhando cada vez mais acentos e ficando cada vez mais longos, influenciando o aumento gradativo da cinesfera na performer. A ideia de contenção é extremamente importante nesse processo e está relacionada com o mapeamento metafórico de um esquema básico da experiência corporal, conforme discutido por BROWER (2000). Essa expansão

\footnotetext{
12 Para uma discussão sobre a noção de gesto em música, inclusive uma definição da sua natureza cognitiva, consultar Bertissolo (2013, 2017) e Gritten e King (2006, 2011).
} 
acaba sendo potencializada na seção central da música, quando os gestos contidos são extrapolados e a pianista passa a explorar toda a extensão do teclado em arpejos, que acabam influenciando a performer a expandir sua cinesfera até abandonar completamente sua posição original, ganhando o palco e se deslocando na cena.

A ideia de complementaridade/contrastes também foi determinante nos processos criativos, uma vez que diversos elementos em cena e na música possibilitaram o desenvolvimento dessa estratégia em relação ao conceito explorado na obra. Primeiramente, havia um contraste forte entre os movimentos de cinesfera pequena e sua expansão gradual na cena, que foi complementada pela projeção ao vivo da própria performer através de uma câmera no palco (na primeira versão, em frente à performer, na segunda, na lateral do piano, captando a performer ao fundo). Essa complementaridade foi potencializada pelos contrastes nos materiais musicais, que foram oriundos de várias naturezas: contraste entre duas transposições da pentatônica entre as teclas brancas e pretas do piano (material principal dos cânticos da Capoeira), contrastes na topologia do teclado (ora com ataques nos extremos, ora com gestos na região central), contrastes nas dinâmicas, ora com ataques incisivos, ora em sussurros. Na terceira seção da peça, os gestos da primeira seção são retomados, mas em um processo de contração, e com a inversão da ordem das transposições no piano (as teclas pretas na mão esquerda dão lugar às brancas, enquanto as brancas da mão direita, às pretas).

O Estado de Prontidão também se revela um forte elemento de jogo no domínio da expectativa/surpresa. Isso ocorre em Converse, desde os acentos aleatórios e ataques, descritos anteriormente, mas também a partir de um elemento musical específico. As duas transposições da coleção pentatônica resultaram em 10 notas, deixando as notas Fá e Si de fora dos gestos iniciais. Durante as sessões de colaboração, decidimos preparar essas duas notas, inserindo moedas entre as cordas do piano. O resultado foi uma alteração nas sonoridades dessas duas teclas, que são pouco a pouco inseridas ao longo da peça. Como a eletrônica processa e potencializa esses sons em tempo real, o ouvinte pode se perguntar se esses sons são oriundos da eletrônica ou são produzidos durante a performance. Ao longo da escuta esses sons acabam sendo incorporados na sonoridade da peça, sempre deixando uma dúvida no público. Em alguns momentos, ao perceber uma relação entre os gestos da pianista e as sonoridades, o ouvinte pode revisar seu modelo de escuta, causando o que HURON (2006, p. 270) define como Surpresa Consciente ${ }^{13}$, relacionada à expectativa da memória de trabalho.

\footnotetext{
13 Podemos mencionar também efeitos da eletrônica, como glissandos de notas/acordes no piano, que são acusticamente impossíveis de serem realizados e que, quando ocorrem, podem levar o público a revisar seu modelos de escuta, questionando-se: "será que o que ouvi era o piano ou a eletrônica?". Para uma abordagem sobre a psicologia da expectativa, consultar HURON (2006), e para a surpreendibilidade, consultar Bertissolo $(2013,2017)$.
} 


\section{Considerações finais}

Nesse artigo apresentamos um processo colaborativo que tomou a pesquisa performativa como horizonte metodológico. Buscamos, a partir de um processo interartístico colaborativo, desenvolvido a partir de um conceito inferido em um contexto cultural, problematizar os caminhos da pesquisa que partem da imbricação entre teorias e práticas.

Entendemos que Converse se mostrou um processo colaborativo em um sentido amplo da palavra, onde todos os colaboradores participaram ativamente de todas as instâncias de decisão, em um processo horizontal de criatividade distribuída. Tornou-se evidente o Estado de Prontidão como uma condição para uma obra colaborativa acontecer, no tocante que, se o artista compõe sua obra (solo) pressupondo suas experiências vivenciadas, uma colaboração precisa estar aberta ao mundo vivenciado por todos envolvidos. Assim, esse conceito pressupõe um estado de abertura que viabiliza um fazer complexo de se concretizar. Isto está longe de ser uma soma e sim um emaranhado dinâmico.

Essa experiência tornou ainda mais evidente a complexidade que ocorre no jogo de capoeira. é, de fato, uma condição. Assim como estar na roda (de capoeira) é estar vulnerável ao que vai acontecer, em Converse nos colocamos à prova para propor uma interação que só acontece no decorrer da obra, seja na relação com os vídeos, a música eletrônica ou as dinâmicas entre a performance do piano e de movimento. Na figura 9 apresentamos uma síntese sobre a obra Converse, com os elementos do conceito de estado de prontidão, a configuração da obra, bem como seu processo de criação.

\section{Síntese}

\begin{tabular}{|c|c|c|c|}
\hline Obra & Configuração & Conceitos e seus elementos & Processo de criação \\
\hline Converse & $\begin{array}{l}\text { Apresentação com } \\
\text { performance ao vivo } \\
\text { em cena, projeção de } \\
\text { de vídeos } \\
\text { processados em } \\
\text { tempo real e piano } \\
\text { ao vivo }\end{array}$ & $\begin{array}{l}\text { Estado de Prontidão: } \\
\text { - manter-se alerta e } \\
\text { disponível } \\
\text { • imprevisibilidade } \\
\text { - capacidade de resolução de } \\
\text { desafios corporais }\end{array}$ & $\begin{array}{l}\text { - composição não } \\
\text { hierarquizada } \\
\text { - imprevisibilidade das } \\
\text { proposições e } \\
\text { desdobramentos } \\
\text { - vídeo processado em } \\
\text { tempo real } \\
\text { - captação e projeção de } \\
\text { imagem ao vivo } \\
\text { - jogo entre som e } \\
\text { movimento }\end{array}$ \\
\hline
\end{tabular}

Figura 9 - Quadro síntese sobre Converse, o conceito de estado de prontidão e o processo de criação 
Sob o ponto de vista metodológico, ressaltamos a importância dos rascunhos do processo, bem como da documentação em imagens e vídeos, que, além de permitirem a incorporação de traços do processo na obra Converse, possibilitaram também um rico material para reflexão e aprofundamento. Esse texto apresenta-se potencializado pelas imagens, rascunhos e links para conteúdo audiovisual que permitem ao leitor um mergulho no universo criativo, sem o qual não é possível recobrir os caminhos metodológicos performativos e colaborativos que deram vazão ao processo de criação discutido.

Propomos que a metodologia performativa, atualizada pela visão da colaboração interartística, representa um interessante caminho para a pesquisa nos processos criativos contemporâneos. Nesse sentido, argumentamos que o processo e as discussões levantadas nesse texto estão em consonância com o que Reinaldo Ladagga (2012, p. 9) define como a criação de ecologias culturais, onde um crescente número de artistas tem se interessado no desenvolvimento de obras que requerem universos complexos, envolvendo diferentes domínios, à despeito da criação exclusiva de novas obras.

Destacamos ainda que Converse já foi reapresentada em outubro de 2019 no Congresso da UFBA e vem se reestruturando constantemente partindo da observação e análise dos nossos próprios olhares e fazeres sobre a obra, num processo contínuo. Podemos citar, por exemplo, alterações no layout do palco partindo de demandas percebidas em sua estreia, além de novas propostas de movimento partindo do desenvolvimento da pesquisa de Lia após sua defesa. Além disso, a peça foi gravada por Luciane Cardassi em maio de 2019 no Banff Centre for Arts and Creativity, no Canadá, e estamos trabalhando numa versão em vídeo que muito em breve deverá estar disponível para apreciação. Converse foi também o tema de duas comunicações de pesquisa apresentadas pelos autores em 2019: no XIV Simpósio Internacional de Cognição e Artes Musicais (Campo Grande, MS) e no XXIX Congresso da Associação Nacional de Pesquisa e Pós-graduação em Música (Pelotas, RS). Nessas ocasiões, por questões logísticas, a obra foi apresentada sem a performance cênica (por Luciane e Guilherme), que foi apenas apresentada em vídeo.

Além de buscar novas oportunidades de apresentação pública de Converse, e de lançamento de uma versão do trabalho em vídeo, a elaboração deste artigo nos instiga a continuar reflexões, que apenas apontamos neste texto, no que diz respeito aos processos de criação, principalmente a noção de gesto, o tema de contenção/expansão, complementaridade/contrastes e as ideias de expectativa/surpresa. Os processos de construção de sentido, seja na composição musical, seja na performance, podem ser desdobrados pela perspectiva da cognição incorporada. Nesse sentido, um dos desdobramentos futuros envolve o aprofundamento desses processos à luz da literatura sobre gesto (GRITTEN; KING 2006, 2011) e a noção de forças musicais (LARSON, 2012), 
performatividade (NAGY, 2017), expectativa e surpresa (HURON, 2006) e esquemas musicais (BROWER, 2000).

\section{Referências}

BACON, Jane; MIDGELOW, Vida. Creative articulations process. Choreographic Practices, v. 5, n. 1, p. 7-31, 2014.

BACON, Jane; MIDGELOW, Vida. Processo de articulações criativas (pac). In: SILVA, C. R. et al. (Ed.). Resumos do 5ํㅡㄴ Seminário de Pesquisas em Andamento PPGAC/USP. São Paulo: PPGAC/ECA-USP, 2015. v. 3.1. Tradução de Eduardo Augusto Rosa Santana, revisão de Pedro de Senna.

BERTISSOLO, Guilherme. Composição e Capoeira: dinâmicas do compor entre música e movimento. Tese de Doutorado, Programa de Pós-Graduação em Música/Universidade Federal da Bahia, 2013.

BERTISSOLO, Guilherme. Composição e cognição: Contribuições da cognição incorporada para a criação de estratégias para o compor. Revista Percepta, vol. 5, n. 1, 2017.

BROWER, Candace. A cognitive theory of musical meaning. Journal of Music Theory, v. 44, n. 2, p. 323-379, 2000.

CARDASSI, Luciane; BERTISSOLO, Guilherme. Shared musical creativity: teaching composerperformer collaboration. Revista Vórtex, Curitiba, v.8, n.1, p. 1-19, 2020.

CLARKE, Eric; DOFFMAN, Mark. Distributed Creativity: Collaboration and Improvisation in Contemporary Music. 2017.

DOFFMAN, Mark; CALVIN, Jean-Philippe. "Contemporary Music in Action: performer-composer collaboration within the conservatoire". In CLARKE, Eric; DOFFMAN, Mark. Distributed Creativity: Collaboration and Improvisation in Contemporary Music. Oxford University Press, 2017.

FERNANDES, Ciane. Dança Cristal: da arte do movimento à abordagem somático-performativa. Salvador: EDUFBA, 2018.

FERNANDES, Ciane. Em busca da escrita com dança: algumas abordagens metodológicas de pesquisa com prática artística. Dança: Revista do Programa de Pós-Graduação em Dança, v. 2, n. 2, p. 18-36, 2013.

FERNANDES, Ciane. O corpo em movimento: o sistema Laban/Bartenieff na formação e pesquisa em artes cênicas. 2 ed. revisada e ampliada. ed. São Paulo: Annablume, 2006.

FERNANDES, Ciane. Pesquisa somático-performativa: Sintonia, sensibilidade, integração. Art Research Journal/ Revista de Pesquisa em Arte, v. 1, n. 2, p. 76-95, 2014.

FERNANDES, Ciane. Princípios em movimento na pesquisa somático-performativa. In: SILVA, C. R. et al. (Ed.). Resumos do $5^{\circ}$ Seminário de Pesquisas em Andamento PPGAC/USP. São Paulo: PPGAC/ECA-USP, 2015. v. 3, n. 1, p. 81-95.

FERNANDES, Ciane. Quando o todo é mais que a soma das partes: somática como campo epistemológico contemporâneo. Revista Brasileira de Estudos da Presença - Brazilian Journal on Presence Studies, v. 5, n. 1, p. 9-38, 2015.

FITCH, Fabrice; HEYDE, Neil. "'Recercar' - the collaborative process as invention", Twentieth-century music. Vol. 4 no.1, 2007. p. 71-95.

GRITTEN, Anthony; KING, Elaine. Music and Gesture. Hampshire/Burlington: Hashgate, 2006.

GRITTEN, Anthony; KING, Elaine. New perspectives of music and gesture. Hampshire/Burlington: Hashgate, 2011.

HAYDEN, Sam; WINDSOR, Luke. Collaboration and the composer: case studies from the end of the 20th century. Tempo, Cambridge, v. 61, n. 240, 2007. p. 28-39. 
HURON, David. Sweet anticipation: music and the Psychology of expectation. Cambridge/MA: MIT Press, 2006.

JOHN-STEINER, Vera. Creative Collaboration. New York: Oxford University Press, 2000.

LABAN, Rudolf. Dança educativa moderna. Tradução: Maria da Conceição Parayba Campos. São Paulo: Ícone, 1990.

LABAN, Rudolf. Domínio do movimento. São Paulo: Summus Editorial, 1978.

LABAN, Rudolf. The language of movement. Boston: Plays Inc., 1974.

LADAGGA, Reinaldo. Estética da emergência: a formação de outra cultura das artes. São Paulo: Martins Fontes, 2006.

LARSON, Steve. Musical Forces: Motion, Metaphor, and Meaning in Music. Bloomington: Indiana University Press, 2012.

LIMA, Paulo Costa. Cultural perspectives in music composition: the case of the composition movement in Bahia-Brazil. Orfeu, vol. 5, n. 1, 2020.

LIMA, Paulo Costa. Teoria e prática do compor l: diálogos de invenção e ensino. Salvador: EDUFBA, 2012.

MESTRE NENEL (MACHADO, Manoel Nascimento). BIMBA: um século da Capoeira Regional. Organizado por Lia Sfoggia. Salvador: EDUFBA, 2018.

MORIN, E. Introdução ao pensamento complexo. Tradução de Eliane Lisboa. Porto Alegre: Sulina, 2006.

NAGY, Zvonimir. Embodiment of Musical Creativity: the Cognitive and Performative Causality of Musical Composition. New York/London: Routledge, 2017.

SFOGGIA, Lia G. Corpos que são: a Capoeira Regional Reverberada em Processos Criativos em Arte. 163 p. Tese de Doutorado. Programa Multidisciplinar de Pós-Graduação em Cultura e Sociedade - Instituto de Humanidades, Artes e Ciências da UFBA, 2019.

STYLES, Luke. Collaboration as Compositional Process: a Transdisciplinary Perspective. Doctoral thesis, Trinity Laban Conservatoire of Music and Dance/City University London, 2016. 